\title{
STRATEGI ORGANISASI PENANGANAN TURNOVER MELALUI PEMBERDAYAAN KARYAWAN
}

\author{
Yohana Caroline Iskandar ${ }^{1}$ \\ Dedi Rianto Rahadi ${ }^{2}$ \\ yohana.iskandar@student.president.ac.id ${ }^{1}$ \\ dedi1968@yahoo.com ${ }^{2}$ \\ President University
}

Diterima : November 2020, Disetujui : Desember 2020, Dipublikasikan: Januari 2021

\begin{abstract}
Employee turnover may be common for a company. But if the employees turnover is very large, this will be a problem and the company could suffer big losses. The purpose of this study is to get out of employee turnover through employee empowerment in the hope that it can be reduced or even eliminated employee turnover. This research uses literature method. The strategy taken to overcome this problem is to enter into work agreements with new employees. The work agreement contains several things, namely: 1). The period of time allowed specifically for new employees who are accepted to resign 2). Employees who have been accepted but have not expired their contract, and want to resign, are required to reimburse the training costs. The next strategy for performance monitoring \& internal motivation is to assess that leadership is not only with the manager, but also within each employee. This empowerment will make employees observant in everything that exists, in the organization. This accuracy makes the potential of employees to be extracted optimally, so that work is high and the intensity of participation is low. Empowerment of employees can be done through further study activities, providing challenges, giving freedom to innovate in completing tasks, and ensuring job security. Furthermore, organizations can also offer promotions based on work performance, open seniority. This conducive situation will reduce the intensity of voters.
\end{abstract}

Keywords : performance employees, turnover, work motivation

\begin{abstract}
ABSTRAK
Keluar masuk (turnover) karyawan mungkin adalah hal biasa bagi suatu perusahaan. Tapi jika karyawan yang turnover dengan jumlah sangat banyak, ini akan menjadi masalah dan bisa saja perusahaan mengalami kerugian besar. Tujuan dari penelitian ini adalah untuk menangani turnover karyawan melalui pemberdayaan karyawan dengan harapan dapat mengurangi bahkan menghilangkan turnover pada karyawan. Penelitian ini menggunakan metode literatur. Strategi yang dilakukan untuk mengatasi permasalahan ini adalah melakukan perjanjian kerja dengan karyawan baru. Perjanjian kerja tersebut berisi beberapa hal, yaitu: 1). Jangka waktu yang diijinkan khusus karyawan baru yang diterima untuk mengundurkan
\end{abstract}


diri. 2). Karyawan yang telah diterima namun belum habis masa kontraknya, dan ingin mengundurkan diri, maka ia diharuskan mengganti biaya pelatihan. Strategi selanjutnya untuk memunculkan dorongan berprestasi \& motivasi internal yaitu memberi penekanan bahwa kepemimpinan tak hanya berada pada pengelola manajemen saja, tapi juga berada dalam setiap diri karyawan. Pemberdayaan ini akan membuat karyawan jeli pada segala sesuatu yang ada, dalam organisasi. Ketelitian itu membuat potensi karyawan tergali dengan optimal, sehingga kepuasan kerjanya tinggi, dan intensitas turnout menjadi rendah. Pemberdayaan karyawan itu bisa melalui kegiatan studi lanjut, memberikan tantangan kerja, memberi kebebasan untuk ber-inovasi dalam menyelesaikan tugas, dan menjamin adanya keamanan kerja. Selanjutnya organisasi juga dapat menawarkan promosi jabatan berdasarkan prestasi kerja, buka senioritas. Situasi kondusif seperti ini akan mengurangi intensi untuk turnout.

Kata Kunci : kinerja karyawan, motivasi kerja, turnover

\section{PENDAHULUAN}

Persaingan industri sekarang semakin lama semakin ketat. Banyaknya persaingan tidak menutup kemungkinan bahwa perusahaan akan mengalami kegagalan. Untuk itu, perusahaan haruslah memperhatikan faktor-faktor yang mungkin akan dapat menyebabkan kegagalan bagi perusahaan itu sendiri dengan serius. Salah satu penyebab kegagalan ini adalah faktor pengelola sumber daya manusia. Untuk mengantisipasi hal tersebut maka diperlukan adanya pengelolaan sumber daya manusia dengan baik.

Turnover adalah keluarnya karyawan dari suatu organisasi tempatnya bekerja. Turnover memang merugikan organisasi, meskipun ada juga turnover yang justru menguntungkan organisasi (Robbins, 1998). Organisasi akan menderita kerugikan bila karyawan yang keluar adalah karyawan yang sudah berpengalaman tinggi, mempunyai kemampuan tinggi dan mempunyai posisi penting. Sebaliknya, organisasi justru akan beruntung, bila karyawan yang keluar tersebut mempunyai posisi tidak penting (marginal). Posisi yang ditinggalkannya akan diisi oleh karyawan lainnya yang sudah menunggu promosi. Pada umumnya, tunover pada organisasi berdampak negatif. Demikian pentingnya isu turnover ini, sehingga isu tersebut telah menjadi salah satu variabel tergantung pada banyak penelitian (Robbins, 1998). Turnover ini berkaitan dengan kepuasan kerja (Medina, 2012). Oleh karena itu organisasi berusaha keras agar para karyawannya mempunyai kepuasan kerja tinggi, sehingga mengurungkan niatnya untuk turnover. Usaha-usaha organisasi tersebut berkaitan dengan tingkat kepedulian pemimpin pada karyawannya. Semakin ia peduli maka semakin rendah kecenderungan karyawan untuk turnover. Kepedulian pemimpin itu biasanya berbentuk program-program pemberdayaan karyawan. Contoh program adalah kesempatan untuk menimba ilmu lanjutan. Persoalannya adalah tidak semua karyawan jeli dengan program-program tersebut. Mungkin saja karyawan justru merasa terbebani oleh programprogram tersebut. Jadi permasalahan dalam tulisan ini adalah karyawan kurang jeli melihat peluang-peluang yang ditawarkan pimpinan organisasi untuk memberdayakan dirinya. Karyawan kurang mempunyai dorongan berprestasi (nAch, need for achievement) yang tinggi. Dampaknya, bila karyawan sedikit saja merasa tidak puas dengan pekerjaannya maka kecenderungannya adalah turnover. Kalau pun tetap setia pada organisasi, maka kesehatan 
mentalnya mungkin terganggu. Ia merasa terpenjara oleh pekerjaan dan organisasinya (Huysse-Gaytandjieva, Groot, \& Pavleva, 2013).

Tujuan tulisan ini adalah untuk menjelaskan tentang strategi organisasi untuk pemberdayaan karyawan sehingga kecenderungan karyawan untuk turnover menjadi berkurang. Tulisan ini lebih berpihak pada karyawan, karena di depan organisasi / pimpinan, karyawan sering merasa subordinat. Manfaat tulisan adalah untuk memberi pencerahan pada karyawan bahwa apa pun kondisi organisasi, ternyata ada sisi-sisi positif yang bisa digali. Proses penggalian sisi positif itu sebenarnya adalah proses pemberdayaan karyawan. Karyawan yang merasa tidak puas dengan pekerjaannya tidak perlu turnover atau terganggu kesehatan mentalnya. Turnover memiliki dampak positif bagi organisasi, yaitu membawa organisasi pada tingkat efisiensi yang lebih tinggi. Turnover dibutuhkan oleh organisasi terhadap karyawan yang memiliki kinerja rendah, namun nilai turnover harus dikendalikan agar organisasi mendapat manfaat atas peningkatan kinerja karyawan baru yang lebih besar dibanding biaya rekrutmen yang dikeluarkan oleh organisasi. Turnover perlu diwaspadai apabila mayoritas karyawan yang meninggalkan pekerjaan atau organisasi merupakan sumber daya manusia yang berkompeten.

\section{TELAAH PUSTAKA}

\section{Pengertian Turnover Karyawan Menurut Para Ahli}

\section{Ronald dan Milkha (2014)}

Menurut Ronald dan Milkha (2014), Turnover adalah kecenderungan atau intensitas individu untuk meninggalkan organisasi dengan berbagai alasan dan diantaranya keinginan untuk mendapatkan pekerjaan yang lebih baik.

\section{Simamora (2004)}

Menurut Simamora, Turnover adalah pemisahan diri secara sukarela oleh seorang karyawan dari organisasi.

\section{Jewell dan Siegall (1998)}

Menurut Jewell dan Siegall, Turnover adalah fungsi dari ketertarikan individu yang kuat terhadap berbagai alternatif pekerjaan lain di luar organisasi atau sebagai penarikan diri dari pekerjaan yang sekarang yang tidak memuaskan.

\section{Robbins dan Judge (2009:38)}

Menurut Robbins dan Judge, Turnover adalah tindakan pengunduran diri secara permanen yang dilakukan oleh karyawan baik secara sukarela atau pun tidak secara sukarela. Turnover dapat berupa pengunduran diri, perpindahan keluar unit organisasi, pemberhentian atau kematian anggota organisasi. 
Rivai (2009:238)

Menurut Rivai, Turnover adalah keinginan karyawan untuk berhenti kerja dari perusahaan secara sukarela atau pindah dari satu tempat ke tempat kerja yang lain menurut pilihannya sendiri.

\section{Jenis-Jenis Turnover}

Menurut Mathis dan Jackson (2000:125), turnover karyawan diklasifikasikan menjadi beberapa jenis, diantaranya yaitu:

a. Berdasarkan kesediaan karyawan, turnover dibagi menjadi:

\section{Turnover secara tidak sukarela}

Turnover ini berupa pemecatan karena kinerja yang buruk dan pelanggaran peraturan kerja. Turnover secara tidak sukarela dipicu oleh kebijakan organisasional, peraturan kerja dan standar kinerja yang tidak dipenuhi oleh karyawan.

\section{Turnover secara sukarela}

Karyawan meninggalkan perusahaan karena keinginannya sendiri. Turnover secara sukarela bisa disebabkan banyak faktor, termasuk peluang karier, gaji, pengawasan, geografi dan alasan pribadi/keluarga.

b. Berdasarkan tingkat fungsionalnya, turnover dibagi menjadi:

Turnover fungsional yaitu Karyawan yang memiliki kinerja lebih rendah, individu yang kurang dapat diandalkan, atau mereka yang mengganggu rekan kerja meninggalkan organisasi.

Turnover disfungsional yaitu Karyawan penting dan memiliki kinerja tinggi meninggalkan organisasi pada saat yang genting.

c. Berdasarkan bentuk pengendalian, turnover dibagi menjadi:

Turnover yang tidak dapat dikendalikan Ini muncul karena alasan di luar pengaruh pemberi kerja. Banyak alasan karyawan yang berhenti tidak dapat dikendalikan organisasi contohnya seperti adanya perpindahan karyawan dari daerah geografis, karyawan memutuskan untuk tinggal di daerah karena alasan keluarga, suami atau istri yang dipisahkan dan karyawan adalah mahasiswa yang baru lulus dari perguruan tinggi.

Turnover yang dapat dikendalikan Ini muncul karena faktor yang bisa dipengaruhi oleh pemberi kerja. Dalam turnover yang bisa dikendalikan, organisasi lebih mampu memelihara karyawan jika mereka menangani persoalan karyawan yang dapat menimbulkan turnover. 


\section{Proses Terjadinya Turnover}

Adapun fase atau tahapan proses terjadinya turnover, yaitu:

- Tahap pertama dimulai ketika karyawan mengevaluasi pekerjaannya yang sekarang, lalu mereka menyadari bahwa mereka puas atau tidak puas dengan pekerjaannya.

- Tahap kedua diawali dari penurunan tingkat kepuasan yang kemudian mempengaruhi penurunan motivasi yang dicirikan dengan stres, sakit fisik, malas bekerja, kualitas rendah, komunikasi personal kurang, masa bodoh dengan tugas pekerjaannya.

- Tahap ketiga karyawan mulai memutuskan untuk berfikir dan berniat keluar untuk mencari pekerjaan baru.

- Tahap keempat karyawan membandingkan pekerjaan alternatif dengan pekerjaannya sekarang serta membuat suatu keputusan untuk tinggal atau keluar dan tahap kelima adalah tindakan untuk tinggal atau keluar dari organisasi.

\section{Faktor Penyebab turnover}

Adapun faktor yang dapat menyebabkan turnover diantaranya:

- Usia

Karyawan yang lebih muda memiliki kemungkinan lebih tinggi untuk keluar. Tingkat turnover yang cenderung tinggi pada karyawan berusia muda disebabkan karena mereka masih memiliki keinginan untuk mencoba pekerjaan.

\section{- Lama kerja}

Turnover lebih banyak terjadi pada karyawan dengan masa kerja lebih singkat. Interaksi dengan usia dan kurangnya sosialisasi awal adalah keadaan yang memungkinkan untuk terjadinya turnover.

\section{- Beban kerja}

Akibat beban kerja yang terlalu berat bisa mengakibatkan seorang pekerja menderita gangguan atau penyakit akibat kerja.

\section{- Faktor lingkungan}

Lokasi yang menyenangkan akan menarik bagi karyawan, demikian pula dengan lingkungan fisik yang bisa berpengaruh pada turnover karyawan.

\section{- Kepuasan kerja}

Berdasarkan hasil penelitian menunjukkan bahwa tingkat turnover dipengaruhi oleh kepuasan kerja seseorang.

\section{- Kepuasan gaji}

Kepuasan kerja karyawan dianggap sebagai penyebab turnover, tapi persepsi karyawan terhadap perlakuan tidak adil dalam hal kompensasi menjadi penyebab lebih kuat.

\section{- Faktor organisasi}

Saat pendatang baru memiliki profil nilai mendekati profil nilai organisasi, maka kemungkinan untuk tetap bertahan di tempat kerja lebih besar.

Indikasi Terjadinya Turnover Intentions Menurut Harnoto (2002:2): “Turnover intentions ditandai oleh berbagai hal yang menyangkut perilaku karyawan, antara lain: absensi yang meningkat, mulai malas kerja, naiknya keberanian untuk melanggar tata tertib kerja, 
keberanian untuk menentang atau protes kepada atasan, maupun keseriusan untuk menyelesaikan semua tanggung jawab karyawan yang sangat berbeda dari biasanya." Indikasi-indikasi tersebut bisa digunakan sebagai acuan untuk memprediksikan turnover intentions karyawan dalam sebuah perusahaan.

\section{Absensi yang meningkat}

Karyawan yang berkinginan untuk melakukan pindah kerja, biasanya ditandai dengan absensi yang semakin meningkat. Tingkat tanggung jawab karyawan dalam fase ini sangat kurang dibandingkan dengan sebelumnya.

\section{Mulai malas bekerja}

Karyawan yang berkinginan untuk melakukan pindah kerja, akan lebih malas bekerja karena orientasi karyawan ini adalah bekerja di tempat lainnya yang dipandang lebih mampu memenuhi semua keinginan karyawan bersangkutan.

\section{Peningkatan terhadap pelanggaran tatatertib kerja}

Berbagai pelanggaran terhadap tata tertib dalam lingkungan pekerjaan sering dilakukan karyawan yang akan melakukan turnover. Karyawan lebih sering meninggalkan tempat kerja ketika jam-jam kerja berlangsung, maupun berbagai bentuk pelanggaran lainnya.

\section{Peningkatan protes terhadap atasan}

Karyawan yang berkinginan untuk melakukan pindah kerja, lebih sering melakukan protes terhadap kebijakan-kebijakan perusahaan kepada atasan. Materi protes yang ditekankan biasanya berhubungan dengan balas jasa atau aturan lain yang tidak sependapat dengan keinginan karyawan.

\section{Perilaku positif yang sangat berbeda dari biasanya}

Biasanya hal ini berlaku untuk karyawan yang karakteristik positif. Karyawan ini mempunyai tanggung jawab yang tinggi terhadap tugas yang dibebankan, dan jika perilaku positif karyawan ini meningkat jauh dan berbeda dari biasanya justru menunjukkan karyawan ini akan melakukan turnover.

\section{Dampak turnover bagi organisasi}

Turnover ini merupakan petunjuk kestabilan karyawan. Semakin tinggi turnover, berarti semakin sering terjadi pergantian karyawan. Tentu hal ini akan merugikan perusahaan. Sebab, apabila seorang karyawan meninggalkan perusahaan akan membawa berbagai biaya seperti:

a) Biaya penarikan karyawan. Menyangkut waktu dan fasilitas untuk wawancara dalam proses seleksi karyawan, penarikan dan mempelajari penggantian.

b) Biaya latihan. Menyangkut waktu pengawas, departemen personalia dan karyawan yang dilatih. 
c) Apa yang dikeluarkan buat karyawan lebih kecil dari yang dihasilkan karyawan baru tersebut.

d) Tingkat kecelakaan para karyawan baru, biasanya cenderung tinggi.

e) Adanya produksi yang hilang selama masa pergantian karyawan.

f) Peralatan produksi yang tidak bisa digunakan sepenuhnya.

g) Banyak pemborosan karena adanya karyawan baru.

h) Perlu melakukan kerja lembur, kalau tidak akan mengalami penundaan penyerahan.

Turnover yang tinggi pada suatu bidang dalam suatu organisasi, menunjukkan bahwa bidang yang bersangkutan perlu diperbaiki kondisi kerjanya atau cara pembinaannya.

\section{METODE PENELITIAN}

Metode penelitian dengan studi literatur (literacy research) yaitu penelitian yang dilakukan oleh peneliti dengan mengumpulkan sejumlah buku buku, majalah yang berkaitan dengan masalah dan tujuan penelitian (Danial dan Warsiah 2009:80).

\section{HASIL DAN PEMBAHASAN}

Turnover secara ringkas berarti karyawan keluar dari organisasi (Evendi \& Dwiyanti, 2013; Moorhead \& Griffin, 1995). Turnover itu bisa dilakukan secara suka rela maupun terpaksa (Robbins, 1998). Turnover yang dilakukan karena terpaksa, biasanya hal itu terjadi karena organisasi mengalami kebangkrutan, sehingga organisasi harus memberhentikan karyawannya. Turnover seperti ini adalah keputusan pimpinan, bukan keputusan karyawan. Karyawan juga terpaksa melakukan turnover ketika ia mencapai usia pensiun, mengalami penyakit atau cacat tubuh (Shaw, Delery, Jenkins Jr., \& Gupta, 1998). Turnover yang sifatnya suka rela biasanya terjadi pada karyawan yang merasa tidak puas dengan keadaan organisasinya tempat bekerja. Jadi hubungan antara turnover dan kepuasan kerja adala korelasi negatif (Medina, 2012). Turnover suka rela juga bisa terjadi ketika organisasi menawarkan program pensiun dini, untuk mempertahankan usia organisasi (Shaw, Delery, Jenkins Jr., \& Gupta, 1998).

Apakah turnover itu merugikan organisasi? Turnover akan merugikan atau menguntungkan organisasi berdasarkan faktor kualitas karyawan. Bila karyawan yang keluar adalah karyawan yang pengalaman kerjanya tinggi, kualitas kerjanya bagus karena sudah mendapatkan berbagai pelatihan dari organisasi dan memegang posisi penting, maka organisasi akan mengalami kerugian besar. Kerugian terjadi karena organisasi sudah mengeluarkan banyak dana untuk mengembangkan karyawan, namun karyawan segera keluar setelah mendapatkan manfaat. Selain itu, kualitas yang bagus dari karyawan telah menyebabkan organisasi tergantung nasibnya pada karyawan tersebut. Apalagi bila karyawan yang berkualitas bagus itu belum sempat / enggan menularkan kemampuannya pada karyawan lain.

Dampak buruk turnover selanjutnya pada organisasi adalah turnover menular pada karyawan lainnya (Nasution, 2009). Organisasi -organisasi yang mempunyai sejarah angka turnover yang tinggi berdasarkan berbagai alasan, cenderung membuat karyawan lama untuk juga 
keluar (Shaw et al., 1998). Terus berada dalam organisasi dengan sejarah turnover tinggi mungkin akan membuat karyawan lama semakin tidak percaya pada organisasi. Apalagi bila mantan karyawan itu ternyata menjadi lebih sukses setelah bekerja pada organisasi lain. Dampak buruk selanjutnya adalah karyawan berkualitas tinggi yang turnover itu ternyata menyebabkan pelanggan juga menghilang. Karyawan berkualitas tinggi berarti ia sudah menghayati rahasia organisasi dalam menarik pelanggan. Bila ia keluar dari organisasi, berarti hilang pula penggannya (Chen, Wang, Chu, 2010). Turnover juga bisa berdampak positif pada organisasi. Bila karyawan yang keluar adalah karyawan yang belum berpengalaman, organisasi belum mengeluarkan dana untuk pengembangan karyawan, ia menduduki posisi yang tidak penting (marginal) dan ia sering merasa tidak puas dengan pekerjaannya, maka organisasi justru akan beruntung (Robbins, 1998). Keluarnya karyawan yang berkualitas rendah tersebut justru membuka peluang bagi organisasi untuk mencari karyawan baru yang kualitasnya lebih baik. Selain itu, posisi yang kosong itu merupakan peluang promosi bagi karyawan lainnya.

Mengapa terjadi turnover? Turnover terjadi karena karyawan merasa tidak puas dengan organisasi tempatnya bekerja. Tidak semua karyawan yang merasa tidak puas akan keluar dari organisasi. Selain keluar dari organisasi (exit), karyawan yang tidak puas terhadap organisasi akan melakukan tindakan lainnya yaitu berdiskusi dengan manajemen agar terjadi perubahan ( voice), berdoa sambil berharap terjadi perbaikan dalam organisasi, atau berperilaku tidak peduli ( neglect) (Matland, 1995; Rusbult, Farrell, Rogers, \& Mainous III, 1988; Rusbult, Zembrodt, \& Gunn, 1982).

Alternatif mana saja yang akan dipilih individu dari empat alternatif di atas, bergantung pada tiga hal. Tiga penentu keputusan individu tersebut ialah ketersediaan alternatif di luar organisasi, kemungkinan pengorbanan yang harus ditanggung bila memutuskan hubungan, dan tingkat pengalaman menyenangkan yang telah diperolehnya dengan organisasi tersebut (Michener \& DeLamater, 1999). Semakin rendah angka pengangguran, semakin sedikit pengorbanan individu kepada oranisasi dan semakin buruk pengalaman individu pada organisasi, maka semakin individu memutuskan untuk keluar dari organisasi.

Selanjutnya juga disebutkan bahwa penyebab turnover adalah banyak faktor. Faktorfaktor tersebut adalah kemenarikan pekerjaan, kemenarikan organisasi, karakter karyawan, kesesuaian antara kualitas karyawan dengan pekerjaan, angka pengangguran dan pengaruh dari keluarga (Moorhead \& Griffin, 1995). Semakin pekerjaan dipersepsikan tidak menarik dan semakin banyak alternatif pekerjaan di luar (angka pengangguran rendah), maka karyawan semakin terdorong untuk turnover (Shaw et al., 1998). Keberadaan karyawan dalam suatu organisasi adalah bukan kebetulan. Karyawan memilih organisasi yang disukainya. Karyawan yang rasa percaya dirinya rendah, cenderung senang dengan organisasi besar. Hal ini karena ia tidak perlu memperlihatkan tanggung jawab yang besar. Bila ia berada pada organisasi kecil, maka mungkin ia akan turnover (Turban \& Keon, 1993).

Melihat begitu berartinya karyawan bagi keberlangsungan organisasi (Luthans, 1995), maka organisasi tentu saja akan mempertahankan karyawan dengan berbagai strategi. Strategi investasi langsung yang dilakukan oleh bagian personalia adalah memastikan bahwa gaji, honor, dan berbagai imbalan lainnya harus berjalan dengan lancar, baik jumlah dan waktu 
pembagiannya (Shaw et al., 1998). Apabila gaji tidak diterimakan secara rutin, maka karyawan akan bertanya-tanya tentang kepastian usia organisasi. Salah satu tanda organisasi akan tutup adalah gaji karyawan sering tersendat.

Untuk mencegah turnover, bagian personalia juga harus melaksanakan strategi investasi yang sifatnya tidak langsung. Strategi itu meliputi stabilitas pekerjaan (ia tidak akan dipecat), pelatihan, dan keadilan prosedural. Selanjutnya strategi itu juga memastikan adanya kesempatan untuk promosi jabatan, adanya program mentoring dari karyawan senior pada karyawan junior, serta adanya saluran komunikasi yang lancar. Keberadaan strategi ini akan berkorelasi negatif dengan turnover suka rela (Chen et al., 2010; Shaw et al., 1998).

Selanjutnya, untuk meminimalkan potensi kerugian maka organisasi juga dapat menerapkan dua kebijakan yaitu:

1. Jangka waktu yang diijinkan bagi karyawan baru yang diterima untuk mengundurkan diri. Hal ini untuk menghindarkan kasus karyawan yang baru masuk beberapa hari namun kemudian ia melakukan turnover. Strategi ini untuk menjaga citra organisasi.

2. Karyawan yang sudah diterima namun belum habis masa kontraknya dan ingin mengundurkan diri, maka ia diharuskan mengganti biaya-biaya pelatihan yang telah diterimanya. Biaya pelatihan tersebut sangat mahal, sehingga karyawan harus berpikir lagi bila akan keluar dari organisasi. Berdasarkan Undang-Undang No. 13 tahun 2003 tentang Ketenagakerjaan, besarnya biaya pelatihan yang harus dikembalikan adalah sebesar upah karyawan sampai batas waktu berakhirnya jangka waktu perjanjian kerja. Strategi-strategi tersebut di atas sebenarnya adalah indikator bahwa organisasi peka terhadap letupan-letupan rasa tidak puas karyawan. Organisasi harus segera bertindak melakukan pembenahan dan penataan kembali semua perangkat organisasi untuk meredam keresahan karyawan. Pembenahan itu juga harus memperhatikan suara-suara karyawan. Pembenahan organisasi yang hanya berdasarkan opini pimpinan saja (misalnya monitoring semua perilaku karyawan secara elektrik), maka hasilnya adalah karyawan justru terdorong untuk turnover secara suka rela (Chen et al., 2010; Shaw et al., 1998).

\section{Faktor Penyebab turnover}

Terdapat beberapa faktor penyebab terjadinya turnover, antara lain yaitu:

1. Usia. Karyawan yang lebih muda lebih tinggi kemungkinannya untuk keluar. Tingkat turnover yang cenderung tinggi pada karyawan berusia muda disebabkan karena mereka masih memiliki keinginan untuk mencoba pekerjaan.

2. Lama kerja. Turnover lebih banyak terjadi pada karyawan dengan masa kerja lebih singkat. Interaksi dengan usia dan kurangnya sosialisasi awal merupakan keadaan yang memungkinkan untuk terjadinya turnover.

3. Beban kerja. Akibat beban kerja yang terlalu berat dapat mengakibatkan seorang pekerja menderita gangguan atau penyakit akibat kerja. 
4. Faktor lingkungan. Lokasi yang menyenangkan akan menarik bagi karyawan, demikian juga dengan lingkungan fisik yang dapat berpengaruh pada turnover karyawan.

5. Kepuasan Kerja. Berdasarkan hasil penelitian menunjukkan bahwa tingkat turnover dipengaruhi oleh kepuasan kerja seseorang.

6. Kepuasan gaji. Kepuasan kerja karyawan dianggap sebagai penyebab turnover, namun persepsi karyawan terhadap perlakuan tidak adil dalam hal kompensasi menjadi penyebab lebih kuat. g. Faktor organisasi. Didapatkan bahwa ketika pendatang baru memiliki profil nilai mendekati profil nilai organisasi, maka kemungkinan untuk tetap bertahan di tempat kerja lebih besar.

\section{Rumus Perhitungan Turnover Karyawan}

Turnover dalam suatu perusahaan dapat diukur berdasarkan indeks laju turnover secara kuantitatif dan dinyatakan dalam persentase berdasarkan jangka waktu tertentu (biasanya dalam 1 tahun). Persentase turnover karyawan dihitung menggunakan rumus sebagai berikut (Hasibuan, 2012:64):

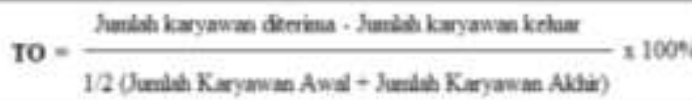

\section{Keterangan:}

- $\mathrm{TO}=$ Persentase Turnover.

- Jumlah yang diterima = jumlah karyawan yang diterima dalam suatu perusahaan.

- Jumlah yang keluar = jumlah karyawan yang keluar dalam suatu perusahaan.

- Jumlah karyawan awal = jumlah karyawan yang diterima pada awal sebelum adanya perekrutan dan keluarnya karyawan.

- Jumlah karyawan akhir = jumlah karyawan yang keluar pada akhir setelah adanya karyawan yang keluar.

\section{Motivasi Internal Dan Intensi Untuk Turnout}

Motivasi Internal dan Intensi untuk Turnout, adanya ungkapan-ungkapan rasa tidak puas karyawan yang kemudian diikuti dengan gelombang turnover, menunjukkan bahwa organisasi sedang tidak sehat. Untuk mencegah turnover, memang sudah seharusnya organisasi mendisain program-program kreatif. Program-program kreatif itu gunanya untuk memberdayakan karyawan. Pemberdayaan berarti karyawan ikut terlibat dalam proses pengambailan keputusan tentang jalannya organisasi. Persoalannya adalah tidak banyak karyawan yang bersedia mengikuti program-program itu. Hal ini mungkin para karyawan itu berada pada posisi penting. Mereka berada pada zona nyaman. Untuk menggugah motivasi internal karyawan, maka organisasi dapat menekankan bahwa kepemimpinan tidak hanya berada pada pengelola manajemen saja, tetapi juga berada dalam setiap diri karyawan. Hal ini 
karena kepemimpinan pada hakekatnya adalah ilusi belaka. Penciptaan ilusi itu untuk memuaskan kebutuhan kita untuk bergantung pada orang lain (Allio, 2013; Shinta, Yudhawati \& Purwaningsih, 2013). Oleh karena karyawan adalah juga sebagai pemimpin, maka karyawan didorong untuk memunculkan potensinya, sehingga motivasi kerjanya lebih didominasi oleh motivasi internal. Untuk memunculkan motivasi internal karyawan sehingga karyawan jeli pada peluang-peluang yang ada pada organisasi, maka organisasi dapat menawarkan pelatihan untuk memunculkan dorongan berprestasi (nach), memberikan tantangan dalam pekerjaan, memberikan kebebasan untuk berinovasi dalam menyelesaikan tugas, namun keamanan kerja tetap terjamin (Samuel \& Chipunza, 2009).

Selanjutnya organisasi juga dapat menawarkan promosi jabatan berdasarkan prestasi kinerja, bukan senioritas. Hal ini karena karyawan yang mempunyai dorongan berprestasi tinggi (nach) cenderung lebih tertarik bekerja pada organisasi yang menawarkan promosi berdasarkan prestasi kerja, bukan senioritas (Turban \& Keon, 1993).

Untuk mencegah karyawan lama yang berprestasi tinggi melakukan turnover, maka organisasi dapat menawarkan program tugas belajar dengan beasiswa. Setelah menyelesaikan pendidikan lanjutan itu, maka karyawan harus mematuhi ketentuan organisasi yaitu $2 n+1$. Mereka harus tetap bekerja di organisasi minimal dua kali masa studi ditambah dengan satu tahun. Kebijakan ini berguna untuk menjadikan karyawan lama sebagai role model / panutan bagi karyawan baru.

Sebagai catatan, rumus $2 \mathrm{n}+1$ tersebut diadopsi dari Peraturan Menteri Energi dan Sumber Daya Mineral No. 020/2007, dan ditujukan pada Pegawai Negeri Sipil di Departemen Energi dan Sumber Daya Mineral. Selain itu, yang dimaksud dengan studi lanjutan adalah tingkat S2 (master) dan S3 (doktor). Meskipun demikian, organisasi swasta pun dapat mengadopsi peraturan tersebut, sepanjang semua perangkat organisasi menyetujuinya.

Dorongan organisasi bagi karyawan untuk mendapatkan motivasi berprestasi melalui berbagai program pencegahan turnover, akan membuat karyawan semakin mengoptimalkan kinerjanya. Ia akan jeli terhadap peluang-peluang yang ada dalam organisasi tempatnya berkarya, untuk mengembangkan potensi dirinya. Semakin ia rajin mengambangkan dirinya, maka turnover akan semakin jauh dari ingatannya. Ia justru asyik membina karirnya.

\section{Turnover Saja Tak Cukup, Ketahui ‘Siapa yang Resign’ Dari Perusahaan}

Merekrut dan mempertahankan pegawai adalah salah satu kunci yang memengaruhi pertumbuhan perusahaan. Perputaran karyawan (turnover) yang cepat menimbulkan kerugian baik dari segi finansial maupun moral pada perusahaan dan karyawan yang masih bekerja.

Mengacu pada Gallup, turnover yang ideal adalah 10\% dalam setahun. Tapi, persentase ideal bisa berbeda antara satu industri dengan industri lain dan satu perusahaan dengan perusahaan lainnya.

Namun, perusahaan tak cukup hanya menilai rendah tingginya turnover, karena bisa jadi turnover yang masih termasuk ideal berdasarkan standar Gallup, ternyata berpengaruh 
signifikan terhadap bottom line perusahaan. Oleh karena itu, hendaknya perusahaan melihat 'Siapa yang keluar' untuk mencari tahu akar masalah dan mengatasinya.

\section{Siapa yang keluar?}

Istilah turnover bukan metrik yang cukup baik untuk menganalisa akar masalah. Perusahaan perlu menggunakan metrik lainnya yang lebih detail yaitu 'siapa yang keluar'. Jika dari sebuah persentase turnover mayoritasnya adalah para top performers dan top-tier, maka bisa jadi pertanda bahwa ada masalah yang sangat vital dalam perusahaan, entah itu masalah manajemen, kultur atau gaji yang membuat mereka merasa disengaged dan memutuskan keluar.

Padahal, keluarnya para top performers membawa dampak signifikan bagi perusahaan karena outputmereka empat kali lebih besar daripada karyawan biasa dengan gaji yang setara. Bisa jadi hubungan perusahaan dengan konsumen terganggu, bahkan putus hubungan, dan inilah yang kemungkinan akan memberikan dampak signifikan terhadap bottom line perusahaan.

Keluarnya para top-tier position juga memberikan dampak signifikan yaitu terhadap produktivitas dan ROA perusahaan. Proses untuk mencari pengganti kedua kelompok karyawan tersebut pun tak akan mudah dan memakan cost yang tidak sedikit.

Sedangkan jika turnover tinggi pada low performers, bisa jadi membawa dampak positif bagi banyak aspek, mulai dari employee engagement, produktivitas hingga profit, asalkan kita bisa meminimalkan persentasenya dan menggantinya dengan sumber daya manusia yang kualitasnya jauh lebih baik. Turnover rate tinggi pada low performers mengindikasikan perusahaan perlu melakukan perbaikan pada proses rekrutmen.

Adapun turnover tinggi pada kelompok new-hired, kemungkinan besar menandakan ada masalah dalam proses seleksi, onboarding dan/atau proses training.

\section{Ciptakan turnover ideal}

Para peneliti percaya bahwa employee engagement menjadi kunci untuk mengatasi umumnya masalah turnover yang tinggi. Seperti dikatakan sebelumnya, turnover ideal bisa jadi berbeda bagi tiap industri dan perusahan. Maka, akan sangat bijak jika apapun program employee engagement yang hendak dilakukan perusahaan selayaknya berfokus pada pengurangan turnover pada top performers dan top-tier hingga mendekati $0 \%$ dan turnover pada low performers setidaknya di bawah $10 \%$.

Perusahaan juga perlu memerhatikan tingkat turnover pada average performer yang umumnya merupakan populasi terbesar dalam sebuah perusahaan. Memang tingkat turnover yang tinggi pada average performer tak memberikan dampak sebesar turnover pada top performer dan top tier, namun harus tetap diperhatikan dan dikendalikan.

Dampak terbesar dari turnover pada average performers adalah biaya rekrutmen dan biaya saat posisi kosong. Adapun biaya untuk meretensi average performer jauh lebih murah dari kombinasi biaya rekrutmen dan biaya saat posisi kosong. Itu artinya, strategi meretensi karyawan juga perlu difokuskan pada average performers. 
Faktor yang Mempengaruhi Turnover Intention Turnover intention tidak berdiri sendiri, ada hal-hal yang mendorong terjadinya perilaku karyawan tersebut. Seseorang tidak akan meninggalkan organisasi tanpa suatu alasan/ faktor yang memicu timbulnya keinginan untuk berpindah/ turnover intention. Menurut Mobley (2011) faktor faktor yang mempengaruhi munculnya turnover intention adalah:

a. Faktor individual, termasuk di dalamnya adalah usia, masa kerja, jenis kelamin, pendidikan, dan status perkawinan.

b. Kepuasan kerja, menyangkut beberapa aspek operasional, yakni kepuasan terhadap gaji atau sistem pembayaran, kepuasan terhadap penyeliaan, kepuasan terhadap bobot pekerjaan, kepuasan terhadap promosi jabatan, ataupun kepuasan terhadap kondisi kerja perusahaan pada umumnya.

c. Komitmen organisasional, tidak adanya komitmen organisasional dapat membuat seseorang karyawan yang puas terhadap pekerjaannya mempunyai niat untuk keluar atau pindah ke perusahaan lain. Namun, seorang karyawan bisa tidak puas terhadap pekerjaan, tetapi tidak emiliki niat untuk keluar atau pindah ke perusahaan lain karena adanya komitmen yang kuat antara dirinya dengan perusahaan tempat ia bekerja. Oleh karena itu, ia akan tetap bekerja untuk melakukan yang terbaik disertai dengan adanya dorongan yang kuat untuk tetap menjadi anggota perusahaan. Faktor - faktor berikut ini disebutkan oleh Pasewark dan Strawser (dalam Toly, 2001) sebagai penyebab dari turnover intention: a. Komitmen organisasi. Karakteristik komitmen organisasi antara lain adalah: loyalitas seseorang terhadap organisasi, kemauan untuk mempergunakan usaha atas nama organisasi, kesesuaian antara tujuan seseorang dengan tujuan organisasi (goal congruence), dan keinginan untuk menjadi anggota organisasi.

b. Kepuasan kerja Orientasi individu yang berpengaruh terhadap peran dalam bekerja dan karakteristik dari pekerjaannya. Yang membedakan dengan komitmen organisasi adalah pada luasnya karakteristik yang dirasakan individu.

c. Kepercayaan organisasi Gambaran dari kemampuan yang diperlihatkan oleh organisasi untuk memenuhi komitmen organisasi tersebut terhadap karyawannya. Dari penjelasan di atas, dapat disimpulkan bahwa faktor penyebab turnover menurut Mobley (2011) adalah faktor individual yang mencakup usia, masa kerja, jenis kelamin, pendidikan, dan status perkawinan. Kepuasan kerja, yang menyangkut beberapa aspek operasional, yakni kepuasan terhadap gaji, kepuasan terhadap penyeliaan, kepuasan terhadap bobot pekerjaan, kepuasan terhadap promosi jabatan, ataupun kepuasan terhadap kondisi kerja perusahaan pada umumnya, komitmen kerja, kepuasan kerja dan kepercayaan organisasi. Berdasarkan penjelasan dari faktor-faktor di atas, maka peneliti memilih faktor menurut Mobley yaitu faktor individual yang mencakup usia, masa kerja, jenis kelamin, pendidikan, dan status perkawinan. Faktor kepuasan kerja, yang menyangkut beberapa aspek operasional, yakni kepuasan terhadap gaji, kepuasan terhadap penyeliaan, kepuasan terhadap bobot pekerjaan, kepuasan terhadap promosi jabatan, ataupun kepuasan terhadap kondisi kerja perusahaan pada umumnya. Selain itu juga faktor komitmen organisasial yaitu terkait komitmennya terhadap 
perusahaan tempat karyawan tersebut bekerja. Peneliti memilih faktor kepuasan kerja karena faktor kepuasan kerja mempunyai pengaruh terhadap turnover intention karyawan yang berada di dalam perusahaan dimana karyawan yang tidak puas cenderung ingin pindah atau berhenti dari tempatnya bekerja.

\section{SIMPULAN}

Tujuan tulisan ini adalah untuk menjelaskan tentang strategi organisasi untuk pemberdayaan karyawan sehingga kecenderungannya untuk turnover menjadi berkurang. Strategi organisasi yang bersifat investasi langsung adalah memastikan bahwa gaji, honor, dan berbagai bonus harus diberikan kepada karyawan baik dalam hal jumlah maupun waktu pemberiannya. Strategi investasi tidak langsung adalah berupa kesempatan bagi karyawan untuk mengembangkan diri. Disebut investasi tidak langsung karena dampaknya tidak langsung bagi pengembangan diri karyawan. Karyawan yang mampu mengembangkan diri berarti ia mampu memberdayakan dirinya. Ia menjadi jeli pada peluang-peluang yang disodorkan organisasi untuk menaikkan kemampuannya. Karyawan yang tergali potensinya akan tinggi juga kepuasan kerjanya, sehingga intensi turnover justru menurun.

\section{REFERENSI}

Allo, R. J. (2013). Masterclass: Leaders and leadership. Strategy and Leadership. 41(1), Emerald Publishing Limited, DOI /

Chen, Y.C., Wang, W.C. \& Chu, Y.C. (2010) Structural investigation of the relationship between working satisfaction and employee turnover. The Journal of Human Resource and Adult Learning. 6(1), June,

Evendi, R. \& Dwiyanti, R. (2013). Hubungan antara hardiness (kepribadi an tahan banting) dengan intensi turnover pada karyawan PT Sumber Alfaria tbk di wilayah Gombong Kabupaten Kebumen. Psycho Idea. 11(2), Juli, ISSN

Huysse-Gaytandjieva, A., Groot, W. \& Pavleva, M. (2013). Why do some employees fall into and fail to exit a job-lock situation?. Journal of environemntal and Public Health Article ID

Luthans, F. (1995). Organizational behavior. 7th ed. New York: McGraw-Hill, Inc. Matland, R. E. (1995). Exit, voice, loyalty, and neglect in urban school system. Social Science Quarterly 76 (3), , September.

Michener, H. A. \& DeLamater, J. D. (1999). Social psychology. 4 th Ed. Philadelphia: Harcourt Brace College Publishers.

Medina, E. (2012). Jo b satisfaction and employeen turnover intention: What does organizational culture have to do with it? Thesis of Masters of Arts. Fall. Columbia University.

Moorhead, G. \& Griffin, R. W. (1995). Organizational behavior. Boston: Houghton Mifflin Company. 
Nasution, W.A., (2009). Pengaruh kepuasan kerja karyawan terhadap intensi turnover pada call center telkomsel di Medan. Jurnal Mandiri. 4(1), Februari, ISSN

Peraturan Menteri Energi dan Sumber Daya Mineral Nomor 020 tahun 2007, tentang pedoman pelaksanaan tugas belajar pendidikan pascasarjana program magister I master (S2) dan doktor (S3) dalam negeri dan luar negeri di lingkungan Departemen Energi dan Sumber Daya Mineral.

Robbins, S.P. (1998). Organizational behavior. 8 th Ed. International Edition. Upper Saddle River, New Jersey: Prentice-Hall International, Inc.

Rusbult, C. E., Farrell, D., Rogers, G., \& Mainous dkk. (1988). Impact of exchange variables on exit, voice, loyalty, and neglect: An integrative model 799 of responses to declining job satisfaction. Academy of Management Journal, 31(3), Rusbult, C. E., Zembrodt, I. M., \& Gunn, L. K. (1982). Exit, voice, loyalty, and neglect: Responses to dissatisfaction in romantic involvements. Journal of Personality and Social Psychology., 43 (6),

Samuel, M. O. \& Chipunza, C. (2009). Employee retention and turnover: Using motivational variables as a panacea. African Journal of Business Management. 3(8), September, DOI: /AJBM

Shaw, J. D., Delery, J. E., Jenkins dkk. (1998). An organization - level analysis of voluntary and involuntary turnover. Academy Of Management Journal. 41(5),

Shinta, A., Yudhawati, D. \& Purwaningsih, I. E. (2013). Pemimpin psikopat vs karyawan dalam organisasi yang lemah: Strategi memperkuat kesehatan mental karyawan. Prosiding Seminar Nasional. Fakultas Psikologi Universitas Sultan Agung Semarang, 12 Desember.

Turban, D.B. \& Keon, T.L. (1993). Organizational attractiveness: An interactionist perspective. Journal of Applied Psychology.

Hasibuan, Malayu S.P. 2012. Manajemen Sumber Daya Manusia. Jakarta: Bumi Aksara. 